\title{
Criteria for the Classification of the Common Legal Consequences of Criminal Conviction
}

\author{
Vasilisa E. Baskakova ${ }^{1}$, Farit V. Gabdrahmanov ${ }^{1}$, Larisa V. Gorbunova ${ }^{1} \&$ Michail A. Smirnov $^{1}$ \\ ${ }^{1}$ Mari State University, Russia \\ Correspondence: Larisa V. Gorbunova ${ }^{1}$, Law faculty, Mari State University, Lenin square 1, Joshkar-Ola, \\ Republic Mari El, 424001, Russia.
}

Received: February 21, 2015 Accepted: March 15, 2015 Online Published: April 29, 2015

doi: $10.5539 /$ res.v7n8p308

URL: http://dx.doi.org/10.5539/res.v7n8p308

\begin{abstract}
The concept and the content of the common legal consequences of criminal conviction and their classification are studied. As the criteria for the classification of the common legal consequences of criminal conviction have been considered their action in time and in space, the type of the right-restriction subject (holder), the mandatory conviction consequences compliance degree, the restriction degree (levels), the validity of the normative legal acts regulating the conviction consequences, the sector affiliation, the structure (description method), the scope.
\end{abstract}

Keywords: conviction, the common legal consequences of criminal conviction, the classification of criminal conviction consequences

\section{Introduction}

The observance of the rights and liberties of a person and citizen is crucial in the legal state. But how does a crime influence the degree of legal restrictions and scope of rights and freedoms? The society faces two opposite goals that seem to be diametrical. On the one hand, it is necessary to provide the criminal personality with guaranteed constitutional rights and freedoms. However, on the other hand it is necessary to protect the society and the state from the possible repeated relapse into crime. In each country the repeated relapse into crime is different. The rights and liberties of a person and citizen may be limited by federal law only to the extent that is necessary to protect the constitutional order, morality, health, rights and lawful interests of other persons, national defense support and state security.

Unconditionally the criminal punishment and enduring the punishment, the measures of criminal procedure compulsion often deny or restrict the human right to choose the domicile, to occupy certain positions or to engage in certain activities, to participate in elections. Most of the convicts are subject to these restrictions. They arise because of the application of criminal, criminal procedure and penal enforcement laws. The same situation is in the United States, where tens of millions of persons have criminal records. The laws impose considerable restrictions on them, seriously affecting their ability to work and to otherwise exercise the rights of citizens (Annulment of a Conviction of Crime, 1962). Usually these consequences are called direct because direct consequences are the officially sanctioned punishment imposed by the criminal code (Frank, Travis, Reitler, Goulette, \& Flesher, 2009). By the enduring of criminal punishment these restrictions often are not discontinued.

Even after felons complete their sentences, they often find whole classes of key privileges revoked and opportunities blocked (Wheelock, 2005).

Scholars and policy makers wish to eliminate many collateral consequences to promote successful offender reentry (Goulette, Reitler, Frank, Flesher, \& Travis, 2014).

In the American Law (for example, in Ohio) the consequences can be categorized into five common categories:

(1) civil rights; (2) public employment and doing business with the State; (3) care, custody, and control of children and family; (4) regulated professions, occupations, trades, industries, and businesses; and (5) a common category of other privileges (Frank, Lawrence, Reitler, Goulette, \& Flesher, 2009).

Even after felons complete their sentences, they often find whole classes of key privileges revoked and opportunities blocked (Wheelock, 2005). 
According to the Article 86 of the Criminal Code of the Russian Federation a person convicted of an offense is considered to be judged from the date when a judgment of conviction has come into force and until the criminal conviction is canceled or cleared. The conviction record is counted in recidivism and sentencing and it entails other legal consequences in cases and in accordance with the procedure established by federal law (part one). The cancellation or expungement of conviction cancels all legal consequences associated with a criminal record (part six). It does not allow to take into consideration canceled or expunged records when sentencing. Prior to cancellation of conviction it can be expunged by the court or as a result of an amnesty or pardon.

In its decision dated December 23, 2014 the Constitutional Court of the Russian Federation assigns that in its nature the institute of criminal record as a means of criminal law is aimed to ensure the constitutional principle that the law applies to everyone without discrimination in the field of criminal law and it is aimed to achieve a constitutionally significant goals of differentiation of criminal liability and punishment, enhancement its correctional impact on the convict, prevention of new crimes and thus it provides the protection of individuals, society and the state from criminal attacks. In the Criminal Code of the Russian Federation the penal consequences of the criminal record do not go beyond the means of the criminal law that the federal legislator may use to achieve these goals.

Most of the common legal consequences of a criminal record covers the period from serving or executing criminal penalties to cancellation or expungement of conviction.

In the scientific literature the restrictions of rights arising from the fact of criminal record historically are divided into criminal and common law types. For example Evteev (1964), Golina (1979), Eraksin and Pomchalov (1963) and others (Criminal Law, 1994) isolated the effects of criminal law and common law nature. Others directly stressed that state criminal records entail certain legal concequences that can be divided into two groups: common law and criminal law (Shautaeva, 2000).

Also along with common legal and penal consequences the consequences of the penitentiary (Grishko, 2010) or the administrative and legal nature (The Soviet criminal law, 1977) are noted. Emphasizing the diverse nature of the consequences of a criminal record scientists have left unanswered the question of what criteria are taken into account in the classification of the consequences of a criminal record, for example, of the common law nature. In the classification of the consequences of a criminal record an important place takes the systemacity, the ability to control the most important public relations in the area of national security, labor, family relations, participation in elections. In general, the theory and practice of criminal law has begun to classify all the consequences of a criminal record by the branch principal into two large groups: criminal law and common law.

Even in Soviet times there was an ambiguous relation to common legal consequences of a criminal record. Speaking about the appropriateness of such limitations B. S. Nikiforov noted that restriction in human rights for a period of time or permanently due to the fact that the person has served a court sentence means in fact an prior recognition of insufficiency, inadequacy of any applicable by the court penal measures of a criminal impact. A. A. Gerzenzon emphasized the importance of the fact that "stigma of conviction" was not subjected to be eternal, in order the truly reformed and mended the labor way ex-offenders would not be subject to any real limitations in their rights during their life.

The common legal consequences of a criminal record are specified not in criminal or penitentiary legislation but in other federal laws. The authors have noted their diversity. For example, they are regulated by more than 60 federal laws. The presence of such an array of legal restrictions is not known even to the experts.

The authors' scientific interest was provoked by the limitations associated with a criminal record, in foreign countries, for example, in the US, Western Europe and others. Research reveals that conservative climate, religiosity, and racial threat, but not ethnic threat or punitiveness, significantly affect state-level collateral sanctions (Whittle \& Parker, 2014).

The work in this part will continue because the authors had a linguistic barrier. One of the immediate tasks is to make a comparative legal analysis of the legislation on the effects of a criminal record in Russia and foreign countries. The beginning of the research work was initiated at a meeting of the Criminal Law and Procedure Department in Mari State University (2012). The importance of that research was noted and the valuable comments and suggestions were received. In the classification of the general legal consequences of criminal convictions and the determination of the criteria we have previously published the research results of the effect of the consequences of a criminal record during the time. For example, the decisions of the Constitutional Court of the Russian Federation establishing perpetuity convictions and the published scientific article (Gabdrakhmanov, 2013) were analyzed. To the perpetual (lifetime) restrictions we have assigned the conviction consequences that are not limited in time and that are valid after cancellation or expungement of the conviction that means during the 
whole life of a person. An indefinite nature of the criminal record validity is indicated by the words of the law- "a person who had a criminal conviction". Such restrictions as a rule reside in general legal consequences of a criminal record.

Even cancelled or expunged criminal record deprives citizens of the Russian Federation to be appointed as the judge, or to be enrolled to the service in the Investigation Committee of the Russian Federation, in the internal affairs agencies or in the agencies of the prosecutor's office.

The possibility of establishing a perpetual nature of the criminal record consequences may depend on the category and type of a crime, the object of criminal law protection, and a possession of special subject features.

Thus, in the judgment of the Constitutional Court of the Russian Federation dated July 18, 2013 it is said that "the statutes in part that limits the right to choose the occupation and profession for those whose guilt in committing grave and especially grave crimes of said in these statutes, and crimes against sexual inviolability and sexual freedom of the individual - regardless of their severity is established to be entered into force by a court verdict (even if subsequently a criminal record is expunged or cancelled) can not be considered as violating the constitutional principle of proportionality".

Why is this study devoted to common legal consequences of a criminal record? Criminal legal consequences of a criminal record in the Russian criminal law are well studied. At the initial stage of the research, we focused on the classification of the common legal and other consequences of a criminal record. In addition, later we concluded that this issue should be considered in the system connection of the consequences to their criteria.

\section{Materials and Methods}

We have made a research of the criminal convictions consequences in the Criminal Procedure Code and in the Criminal Executive Code. Also we analyzed the historical and contemporary literature, studied federal laws and the laws of the constituent entities of the Russian Federation that provide the restrictions in connection with a criminal record.

The research works of foreign scientists, the articles prepared by the official authorities or public organizations were used in this study.

The methodological basis of the study is the dialectical method of cognition, which helps to reveal a criminal record as an institution of criminal law in the development and in conjunction with the other institutions of the Russian legislation, and based on this method general scientific, special and private-research methods.

\section{Results}

The common legal consequences of the criminal conviction do not occur obligatory. As a rule, they are usually caused by several conditions prescribed by law. The legislator names among them the category, type and specific corpus delict, the form of guilt, the kind of multiple crimes, the crime scene, a form of criminal punishment.

The classification criteria of the common legal consequences of a criminal record is their action in time and space, the type of the right-restriction subject (holder), the mandatory conviction consequences compliance degree, the restriction degree (levels), the validity of the normative legal acts regulating the conviction consequences, the sector affiliation, the structure (description method), the scope.

The effect of conviction consequences in time. By the time the effects of common legal conviction consequences can be divided into urgent (limited to a certain time) and perpetual (lifetime). In the first case, the criminal record consequences act since the verdict comes into force and until the cancellation or expungement of the conviction. Setting the temporary effect of the ccriminal record validity the legislator uses the word "a person having non-canceled or non-expunged conviction" or other words based on these phrases. Perpetual (lifetime) restrictions apply after the cancellation or expungement of the conviction-virtually during the entire human life. The legal term "a person who have a criminal conviction" indicate an indefinite nature of the criminal record validity.

Determing the time terms of the criminal record validity the legislator does not differ constancy and uses different phrases: "suffering non-canceled or non-expunged conviction," "suffering criminal conviction", "suffering or previousely suffered conviction", "suffered or suffering now a criminal record", "does not suffer a criminal conviction", "the current or past criminal record", "the existence of a unexpunged convictions" etc. Different semantic value is often imbedded in the content of these concepts. It leads to a contradictory jurisprudence (Beketov \& Surgutskov, 2008).

Depending on the action of the consequences in the space the criminal record can extend its effect on the entire territory of the Russian Federation or its part (certain places, closed cities, border areas, the constituent entities of the Russian Federation). 
The right-restriction subject (holder). Depending on the characteristics of the right-restriction subjects (holders) they can be divided into basic and advanced (subsidiary) types. The basic subject is the natural person who has or had a criminal record. Subsidiary is another entity specified by. For example, a legal entity where the accused person is employed or has with it another type of relationship.

In certain cases, the criminal conviction consequences (an obligation to inform or to indicate in the application form for a job etc.) may require legal actions from close relatives.

Depending on the affiliation to the state the right-restriction subjects can be citizens of the Russian Federation, foreign citizens and stateless persons.

By the degree of conviction consequences bindingness they may be obligatory (mandatory) and dispositive. In most cases, the law establishes a mandatory (mandatory) implementation of the criminal record consequences.

According to the degree (level) of restrictions on the rights and freedoms usually 4 levels are pointed.

The level zero does not imply any restrictions on the person having (had) a criminal record and on other persons.

The first level (minimal) does not provide the imposition of any restrictions on the person with a criminal record, but it may have negative legal consequences for his relatives or entities where that person is employed or for the entities with which he has other relations.

The second level (medium) limits the rights and freedoms of a person and other entities within the time limits of the conviction prior to its cancellation or expungement.

The third level (maximum and the hardest) assumes a complete ban on certain activities, inclusive of labor, not only for the period of the conviction but also for the entire life. For example, it concerns the service as the prosecutor, judge, police officer.

The criminal record consequences are divided into established by laws and delegated legislation depending on the on the vigor of sources of law. According to the part 3 of article 55 of the Constitution of the Russian Federation the federal law may limit the rights and freedoms of a person and citizen. In practice, their contribution to this constraints process make the constituent entities of the Russian Federation, the Government of the Russian Federation and even the ministries and departments. Thus, in the majority of the constituent entities of the Russian Federation in the absence of federal law there are laws and regulations restricting the participation of convicted persons in the protection of public order.

The criminal record consequences are highlighted by the sector affiliation and they restrict the human rights and freedoms in the sphere of constitutional, civil, criminal procedure, labor, family and other branches of law.

According to the structure (a description method) general legal consequences of a criminal record can be simple or complex. Simple consequences of criminal convictions occur, as a rule, when specifying a single fact of criminal record or in combination with one additional factor. The persons having a criminal record for committing an intentional crime can be studied as an example. Complex consequences as a condition of their occurrence along with a criminal record suggest the presence of 2 or more circumstances. For example, such circumstances can be the category and type of a crime, a form of guilt, etc.

The common legal consequences of a criminal record can be classified into limiting personal (civil), political, social, economic and cultural rights types depending on the scope of the implementation.

The first group of the criminal record consequences is a set of personal (civil) rights restrictions. Such restrictions include the limitations on the freedom of movement and freedom of residence, freedom of honest name and others.

1) The freedom of movement, the freedom of residence and the freedom of unhindered return (chapter 1 of the article 27 of the Constitution of the Russian Federation).

Limitations in this part are usually bound with the presence of a conviction for committing a grave or an especially grave crime.

Thus, toward an emancipated person convicted of a grave or especially grave crime, a crime with a recidivism, an intentional crime against a minor may be set an administrative supervision with the prohibition of stay in certain places, outside the housing accommodations or other premises with the prohibition of departure from the territories established by the court and others. Certain restrictions arising from the fact of the criminal record may relate to foreign nationals or stateless persons.

2) The freedom of honest name (part 1 of the article 23 of the Constitution of the Russian Federation). 
Thus, the scientific and educational institutions, health care institutions, cultural, social security, physical culture and sports institutions which come under the supervision of the federal executive bodies and which receive charitable donations can not be named after the persons who have non-canceled or non-expunged conviction.

The ground for refusal of awarding honorary sports titles is the presence of a conviction for an intentional crime committed by a person presented for the title.

The conviction of a person accused of committing at least one of the offenses set in the articles 205, 205.1, and others of the Criminal Code of the Russian Federation is the basis for a enrolling the person into the list of organizations and individuals with respect to whom there is an evidence of their involvement in extremist activities or terrorism.

The information about previous convictions of the residents of the apartment (apartment house) is entered by the empowered police officer in the passport of the administrative area.

The second group of the common legal consequences of the conviction prevails in the sphere of the political rights which provide the person with the opportunity to participate in the political life of society, in the formation of representative bodies of the state power and local self-government and others.

1) The right to participate in the state affairs, to vote and to be elected to public authorities and local governments, as well as the right to participate in a referendum (part 2 of the article 32 of the Constitution of the Russian Federation).

The criminal record in the circumstances specified by the law is an obstacle to the election of the President of the Russian Federation, the State Duma deputy, the empowering the members of the Federation Council, the election of the highest official of the constituent entity of the Russian Federation (the head of the supreme executive body of the constituent entity of the Russian Federation), the deputy of a representative body of the municipality, the legislative (representative) body of the state power, the elected official.

2) The right to the equal access to the public service (part 4 of the article 32 of the Constitution of the Russian Federation) which is closely related with the right to freely dispose of the abilities to work, choose the type of activity and profession (article 37 of the Constitution of the Russian Federation).

The criminal record is an obstacle in reception of citizens to the civil service and in serving a civil duty.

Even the cancelled or expunged conviction deprives a citizen of the Russian Federation the opportunity to be appointed as the judge, bailiff, adopted for service in the Investigative Committee of the Russian Federation, in the police, in the drug control agencies or in the prosecutor's office and to serve the specified duties.

If a citizen has a convication he can not be hired by the customs authorities or he can not serve in the customs authorities. He can not be called for military service, including the mobilization and contracting for military service in the Armed Forces of the Russian Federation. And he can not hold positions related to the admission to public secret. In some of these cases, the restrictions links to the type and category of the committed offense.

3) Participation in the administration of justice (part 5 of the article 32 of the Constitution of the Russian Federation).

A convicted person can not be a juror, a potential juror, an arbitration court assessor.

4) The right to associate in public organizations (article 30 of the Constitution of the Russian Federation).

A person with a non-canceled or non-expunged conviction for at least one of the offenses under the articles 205, 205.1, 205.2, 205.3, 205.4, 205.5, 206, 208, 211, 220, 221, 277, 278, 279, 280, 280.1, 282, 282.1, 282.2, 282.3 and 360 of the Criminal Code of the Russian Federation can not be a founder, member, participant in public associations.

Citizens with a non-canceled or non-expunged criminal record convicted of premeditated crimes can not be accepted in the vigilante group; can not be founders of national vigilante groups, the founders or members of the public associations of the law enforcement focus or the freelance police officers.

The third group of the common legal criminal record consequences is associated with limited economic rights and freedoms, ensuring the freedom of enterprise and other forms of employment.

1) The restrictions on the freedom of enterprise and other economic activity not prohibited by the law (part 1 of the article 34 of the Constitution of the Russian Federation) can affect both legal entity and a natural person.

Thus, legal entities can not carry out activities related to trafficking of narcotic drugs and psychotropic substances and (or) the cultivation of narcotic plants, if employees that should have an access to such things were previously 
convicted for misdemeanor, grave crime, and especially grave crime or offense associated with illicit trafficking of narcotic drugs, psychotropic substances and their precursors or the illicit cultivation of narcotic plants, including for crimes committed outside the Russian Federation.

The same restrictions apply to individual entrepreneurs in carrying out activities related to trafficking of precursors. Admission of persons who have a conviction for misdemeanor, grave crimes and especially grave crimes or offences that are related to illicit trafficking of narcotic drugs, psychotropic substances and their precursors is prohibited concerning the work directly relating thereto.

When in the non-profit organizations there are the members who have a conviction for economic crimes, and crimes of medium gravity, grave and especially grave crimes such organizations shall not be included in the state register of self-regulating organizations of appraisers. The grounds for refusal of enrolling the legal entity in the state register of credit bureaus is the conviction of committing crimes in the economic sphere by the leaders of the credit bureau and their deputies.

The credit organization may be refused in state registration and issuing it a license to conduct banking transactions when the candidates proposed for the post of the head of the credit organization, the chief accountant of the credit institution and its alternate members of the board of directors (supervisory board) are convicted for crimes in the economic sphere.

The organization may receive a refuse in issuing a license to carry out activities in the field of insurance business when the leaders (including the chief executive officer), or chief accountant of the license applicant have a non-expunged or non-cancelled conviction.

Persons convicted of committing an intentional crime shall not be entitled to acquire the status of private security guard and the license for private detective activity. The founders (participants) of private security organizations, non-governmental educational institutions that provide training for private investigators and employees of private security organizations shall not have a criminal record for committing an intentional crime, as well as legal entities with the founders (participants) that have the specified persons.

The state registration of a person as an individual entrepreneur who intends to carry out certain types of business activities is prohibited if the person has or has had a previous conviction for crimes against life and health, freedom, honor and dignity of the person, sexual integrity and sexual freedom, against the family and minors, public health and public morals, the constitutional order and security of the state, as well as against public safety. The above-mentioned types of business activities include, in particular, activity camps for children during the holidays, preschool and elementary general education activity, hospitals, social services, production and screening of films, sports and recreational activities, and others.

The persons convicted of committing an intentional crime shall not be members of the self-regulatory organization of arbitration managers and of an interim administration financial institution. The shall not act as the sole executive body of the investment fund, its management company, a member of the board of directors (supervisory board), collegial executive body of the investment fund or to be the head of the branch of the management company, etc.

Persons with a criminal record for economic crimes or for intentional crimes of medium gravity, grave crimes, especially grave crimes shall not be organizers of gambling.

Persons convicted for crimes in the sphere of economics or crimes against the state, shall not perform the functions of the sole executive body of the professional securities market participant, a member of the board of directors (supervisory board) and the collegial executive body of the professional participant of the securities market, as well as to perform the functions of the head of the control unit (controller) of the professional securities market participant.

The board of directors of a credit cooperative, auditing body of a credit cooperative (supervisory board of a credit cooperative, audit committee or auditor of a credit cooperative), the sole executive body of the credit cooperative shall not accept as a member a person convicted of a crime in the economic sphere. Similar restrictions apply to housing saving cooperatives.

Housing cooperative board members (including the chairman of the cooperative), a member of the audit commission (auditor) of the cooperative, as well as the chief accountant or an accountant in the absence of a chief accountant in the staffing chart of the cooperative can not be citizens who have convictions for premeditated crimes. 
Persons with a criminal record shall not be members of the supervisory board of an autonomous institution. A simplified procedure for income declaration does not apply to persons who have a criminal record for committing a crime under article 198 of the Criminal Code of the Russian Federation.

There are restrictions on weapon trafficking. Thus, in the state military organizations, organizations with special assignment positions related to accounting, storage, issuance or use of firearms, ammunition and ammunition for firearms can not serve persons who have a previous conviction for an intentional crime. Persons who have criminal record for committing an intentional crime can not be issued a license for the purchase of weapons or a hunting license.

2) The right to freely dispose of the ability to work, to choose the type of the activity and profession (article 37 of the Constitution of the Russian Federation).

The persons who have a criminal record for committing an intentional crime shall not be entitled to acquire the status of a lawyer and to conduct the practice of law, to be attorney's assistants or internes. They shall not be accepted for expert aviation personnel, to work in the service of aviation safety or to work on positions that are directly related to the provision of transport security and the implementation of the cadastral activities. No conviction of an intentional crime is a condition of a membership in the self-regulatory organization of arbitration managers, and also of acquiring a number of positions in the private pension fund. In case a person has a criminal record he shall not be hired as an arbitrator or as an employee by the departmental security.

There are limitaions in acquiring positions in teaching, as well as in the field of education, training, development of minors, the organization of their rest and recovery, health care, social protection and social services in the field of youth sport, culture and art involving minors for the persons who have or have had a previous conviction for crimes against life and health, freedom, honor and dignity of the individual (except illegal placement in a psychiatric hospital, libel and slander), sexual integrity and sexual freedom of the individual, against the family and minors, public health and public morals, the constitutional order and state security, as well as against public safety. Teaching activities are not permitted for persons who have not non-cancelled or non-expunged conviction for premeditated grave or especially grave crimes.

Qualification certificate of the auditor-consultant in the agricultural cooperatives is issued to people with no previous convictions for economic crimes and crimes of medium gravity, grave and especially grave crimes.

The functions of the sole executive body of the professional securities market participant can not carry out the persons convicted for crimes in the sphere of economic activity or against the government. These individuals can not also participate in the board of directors (supervisory board) and the collegial executive body of the professional participant of the securities market, as well as to carry out functions of the head control unit (controller) of the professional securities market participant.

Conditions of membership of a person in a self-regulatory organization of appraisers and of the inclusion of a non-profit organization in the state register of self-regulating organizations of appraisers is the absence among its members persons with an non-expunged or non-cancelled conviction for economic crimes, and crimes of medium gravity, grave and especially grave crimes. Similar requirements apply for membership at a self-regulatory organization of auditors and for membership in a self-regulatory organization of auditors.

A natural person may be certified for the right to draw conclusions on examination of the project documentation and (or) examination results of engineering studies provided that he has no criminal record for committing an intentional crime.

The fourth group consists of the criminal record consequences in the field of social rights of citizens. Their goal is to protect the rights and interests of minors and other most vulnerable segments of the population.

State protection of motherhood, childhood and family (article 38 of the Constitution of the Russian Federation).

The tutors, adoptive parents, foster parents, foster carers shall not be persons who can not be admitted to the teaching, as well as to the work in the field of education, training, development of minors, the organization of their rest and recovery, health care, social protection and social services in the field of youth sport, culture and art involving minors. A temporary transfer of children in the families of the above mentioned persons is also prohibited.

As an expert of information products can not work persons who have or have had a previous conviction for committing grave and especially grave crimes against persons, crimes against sexual inviolability and sexual freedom of the individual, against the family and against minors, intentional crimes against public health and public morals. 
The fifth group consists of the restrictions on cultural rights of citizens, in particular, the right to receive vocational training.

Citizens who have non-cancelled or non-expunged convictions for committing a crime can not be considered for admission to an educational institution for the intended reception and a military training center as well as to participate in the competition for admission to the military training on the military department. Such persons can not be contracted for the training program of reserve officers military training.

The sixth group of the criminal convictions consequences relate to limited rights of citizens to participate in public and other useful activities.

Persons with a criminal record may not be the members of the Public Chamber of the Russian Federation, of the Public Oversight Commission, members of electoral commissions or referendum commission with a casting vote right, public mediator in the financial market (financial ombudsman). They can not carry out activities of a mediator on the non-professional basis.

The absence of the damning action the basis of which can be a consequence of a conviction is a condition for the appointment of members of the public in the qualifying board of judges. A public assistant of the inspector may become a person who has never been prosecuted that means that the person has never had and doesn't have now a criminal record.

\section{Discussions}

We have proposed a detailed classification of the criminal record consequences and their criteria. In foreign legislation conviction consequences are often divided into five main categories: (1) civil rights; (2) employment in the public sector and business with the state; (3) care, custody, and control of children and families; (4) the regulated professions, occupations, industries, enterprises; and (5) general category of other privileges. Obviously, this is determined by the current legislation. In Russian law by the branch accessory we can highlight the consequences in the field of constitutional, civil, criminal procedure, labor, family and other branches of law. The first group of the criminal record consequences are the restrictions of personal (civil) rights. These include restrictions on the freedom of movement and residence, the freedom of honest name and others. Thus, some consequences groups in the Russian and foreign law are the same. On the other hand, the Russian legislation does not provide publication of the previous conviction of an individual or the notice of the general public and private individuals as a conviction consequence.

\section{Conclusion}

The consequences, limiting the personal, political, socio-economic, cultural, human rights, their participation in social and other useful activities are called common consequences. They are set and regulated by more than 60 federal laws. These should be added Decrees of the President of the Russian Federation, Government Resolutions, the laws of constitutional entites of the Russian Federation adopted pursuant to (in some cases, in the absence of) federal laws.

This regulatory framework covers a wide range of legal relations restricting human rights and freedoms. There is a need to harmonize Russian legislation with regard to the criminal record consequences, to adopt a number of federal laws that legitimize regional law-making (for example, the participation of citizens in the protection of public order), to bring the regulations into compliance with the applicable legislation of the Russian Federation.

The collateral consequences of criminal prosecutions are growing in number, scope and duration. These consequences are frequently hidden, making it extremely difficult for judges, practitioners and the public they serve to fully appreciate what lies ahead (Collateral Consequences of Criminal Charges).

The possibility of occurrence of the common legal consequences of a criminal conviction is not absolute and is usually caused by several conditions prescribed by the law. The legislator points out among them the category, the type and specific of the offense, the form of guilt, the kind of multiple crimes, the crime scene, a form of criminal punishment.

The criteria for the classification of the general legal consequences of a criminal conviction are: their action in time and space, the type of the right-restriction subject (holder), the mandatory conviction consequences compliance degree, the restriction degree (levels), the validity of the normative legal acts regulating the conviction consequences, the sector affiliation, the structure (description method), the scope.

\section{References}

Amines, D. I., Belyaeva, L. I., \& Borovikov, V. B. (2009). Russian Criminal Law. Overview: The textbook (p. 496). Moscow: Yustitsinform. 
Annulment of a Conviction of Crime: A Model Act National Council on Crime and Delinquency Crime \& Delinquency (pp. 97-102). (1962).

Beketov, O. I., \& Surgutsky, V. I. (2008). Having been convicted of committing an intentional crime as an obstacle to the issuance of a license for the purchase of weapons to citizens of the Russian Federation. Advokat, 2.

Belyaev, N. A., \& Kovalev, M. I. (1977). Soviet Criminal Law-General Part (p. 457). Moscow: Legal Literature.

Eraksin, V. V., \& Pomchalov, L. F. (1963). Redemption and Removal of Conviction in Soviet Criminal Law (p. 11). Moscow: Publishing House of Moscow State University.

Evteev, M. P. (1964). Cancellation and Expungement of Conviction (p. 6). Moscow: Legal Literature.

Exemption from criminal responsibility and punishment. (2008). Encyclopedia of Criminal Law (T. 10, p. 791, p. 797). St. Petersburg: St. Petersburg HCA.

Frank, J. et al. (2009). Consequences of Criminal Conviction in Ohio. Retrieved from http://www.uc.edu/content/dam/uc/ccjr/docs/reports/Collateral\%20Consequences\%20Final\%20Report.pdf

Gabdrakhmanov, F. V. (2013). Perpetuity consequences of criminal convictions in the decisions of the Constitutional Court of the Russian Federation (pp. 18-25). Collection of scientific works SWorld. Odessa.

Gertsenzon, A. A. (1959). On the Fundamentals of Criminal Legislation of the USSR and the Union Republics (p. 70). Moscow.

Golina, V. V. (1979). Redemption and Removal of Conviction on the Soviet Criminal Law (p. 9). Kharkov: Vishcha School.

Goulette, N., Reitler, A., Frank, J., Flesher, W., \& Travis, L. (2014). Criminal Justice Practitioners' Perceptions of Collateral Consequences of Criminal Conviction on Offenders. Criminal Justice Review, 39. http://dx.doi.org/10.1177/0734016814526752

Grishko, A. Y. (2010). Amnesty. Pardon. Conviction (p. 203, p. 212). Moscow: University Book.

Kozachenko, I. J., \& Neznamova Z. A. (1999). Criminal law. Overview: The Textbook for High Schools (p. 466). Moscow: Publishing. Group NORMA-INFRA.

Krieger, G. A., Kuznetsova, N. F., \& Tkachevsky, Y. M. (1988). Soviet Criminal Law: Overview: Textbook (p. 301). Moscow: MSU.

Menshagin, V. D., Durmanov, N. D., \& Kriger, G. A. (1969). Soviet criminal law: General Part (p. 365). Moscow: Publishing House of the Moscow University.

Menshagin, V. D., Durmanov, N. D., Kriger, G. A., \& Kudryavtsev, V. N. (1974). Soviet Criminal Law: General part (p. 383). Moscow: Publishing House of the Moscow University.

Nikiforov, B. S. (1957). About recidivism and criminal record. The Soviet State and the Right, 5.

Shautaeva, G. H. (2000). A Conviction in Criminal Law and its Legal Significance (pp. 5-6). Izhevsk.

Wheelock, D. (2005). Collateral Consequences and Racial Inequality: Felon Status Restrictions as a System of $\begin{array}{lllll}\text { Disadvantage. Journal of Contemporary } & \text { Criminal }\end{array}$ http://dx.doi.org/10.1177/1043986204271702

Whittle, T., \& Parker, K. (2004). Public Ideology, Minority Threat, and Felony Collateral Sanctions: A $\begin{array}{lllll}\text { State-Level Analysis. Criminal } & \text { Justice } & \text { Review, } & \text { 39(4), }\end{array}$ http://dx.doi.org/10.1177/0734016814543352

Yuzhanin, V. E., \& Armashova, A. V. (2007). The Problem of Recidivism and the Responsibility for it in the Criminal Law of Russia (pp. 15-16). Moscow: Yurlitinform.

Zdravomyslov, B. V., Krasikov, Y. A., \& Rarog, A. I. (1994). Criminal Law-Overview: Textbook (p. 559). Moscow. 


\section{Copyrights}

Copyright for this article is retained by the author(s), with first publication rights granted to the journal.

This is an open-access article distributed under the terms and conditions of the Creative Commons Attribution license (http://creativecommons.org/licenses/by/3.0/). 